\title{
Influence of Cochlear Implantation on Cognitive Function in Elderly Patients
}

\author{
Juyong Chung \\ Department of Otorhinolaryngology-Head and Neck Surgery, Wonkwang University College of Medicine, Iksan, Korea
}

\section{고령 환자에서 인공와우수술이 인지기능에 미치는 영향}

정주용

원광대학교 의과대학 이비인후과학교실

Received December 22, 2021

Revised January 9, 2022

Accepted January 14, 2022

Address for correspondence Juyong Chung, MD, PhD

Department of Otorhinolaryngology-

Head and Neck Surgery,

Wonkwang University

College of Medicine,

895 Muwang-ro,

Iksan 54538, Korea

Tel $+82-63-859-1489$

E-mail claudia7974@naver.com
Hearing loss is the third most common chronic health condition faced by older adults. Recently, a number of studies have demonstrated a significant association between hearing impairment and cognitive decline. However, the underlying explanatory mechanism of this relation has yet to be established. Given the relation between hearing loss and cognitive decline, researchers have been interested in the effect of restoring hearing ability on cognitive functions in older adults. One intervention option for management of the most severe to profound hearing loss in older adults is cochlear implantation (CI). We performed a review to assess the current status of the literature on the potential influence of CI on cognition in the older adults. Hearing rehabilitation through CI in elderly patients results in improvements in speech perception and cognitive function and lowers the progression to dementia. Further well-designed studies with long follow-up are needed to verify whether CI influences cognition in older adults.

Korean J Otorhinolaryngol-Head Neck Surg 2022;65(1):1-9

\section{서 론}

난청은 가장 흔한 인간의 감각장애 중 하나이며, 노인에게 3번째로 흔한 만성질환이다. ${ }^{1)}$ 노화에 의한 퇴행성 변화로, 65세 이상의 고령의 환자들은 난청 발생이 급격히 증가한다. 제8기 국민건강영양조사 결과에 따르면, 65 세 이상의 성인에 서 중증도 이상 난청 유병률은 남성 $44.7 \%$, 여성 $36.2 \%$ 이며, 70세 이상에서는 남성 $54.0 \%$, 여성 $44.5 \%$ 에 달한다. ${ }^{2}$

노인에서 난청과 인지기능 저하와의 연관성은, 청각장애를 가진 노인이 정상 청력을 가진 노인보다 빠른 인지력 저하를 보인다는 결과를 보여주는 전향적이고 종적인(prospective, longitudinal) 많은 연구들을 통해 확립되었다. ${ }^{3-8)}$ 이렇게 청각

This is an Open Access article distributed under the terms of the Creative Commons Attribution Non-Commercial License (https://creativecommons.org/licenses/by-nc/4.0) which permits unrestricted non-commercial use, distribution, and reproduction in any medium, provided the original work is properly cited.
장애와 인지력 저하의 연관성을 보여주는 다년간의 연구들을 연구 기간, 대상 환자 수, 청각장애 평가지표, 인지기능 평가 지표 및 연구결과에 대해 정리해서 Table 1에서 보여주었다. 그러나 아직 노화성 난청과 인지기능 저하의 관련성에 대한 원인 기전은 명확히 밝혀지지 않았고, 복합적인 요인들이 관 여하는 것으로 생각된다.9) 또한, 난청은 치매에 대한 12 가지 위험요인 중, 가장 큰 잠재력을 지닌 수정 가능한 위험 요소 이며, ${ }^{10,11)}$ 난청에 대한 청각적 중재를 통해 치매가 예방될 수 있다는 것을 제안한다. 그러나, 인지기능에 대한 보청기의 효 과는 아직 명확하지 않은데, ${ }^{12,13)}$ 이는 보청기로 인한 청력의 향상이 노인 환자에게 제한적이기 때문이다. 고심도 감각신경 성 난청(profound sensorineural hearing loss) 환자들에게 인공와우 이식술(cochlear implantation)은 유일하게 가능 한 치료법이며, 수술 이후 청력 수준은 크게 향상된다. 이는 인공와우 이식술 이후, 노인의 청각 수준이 인지능력에 긍정 


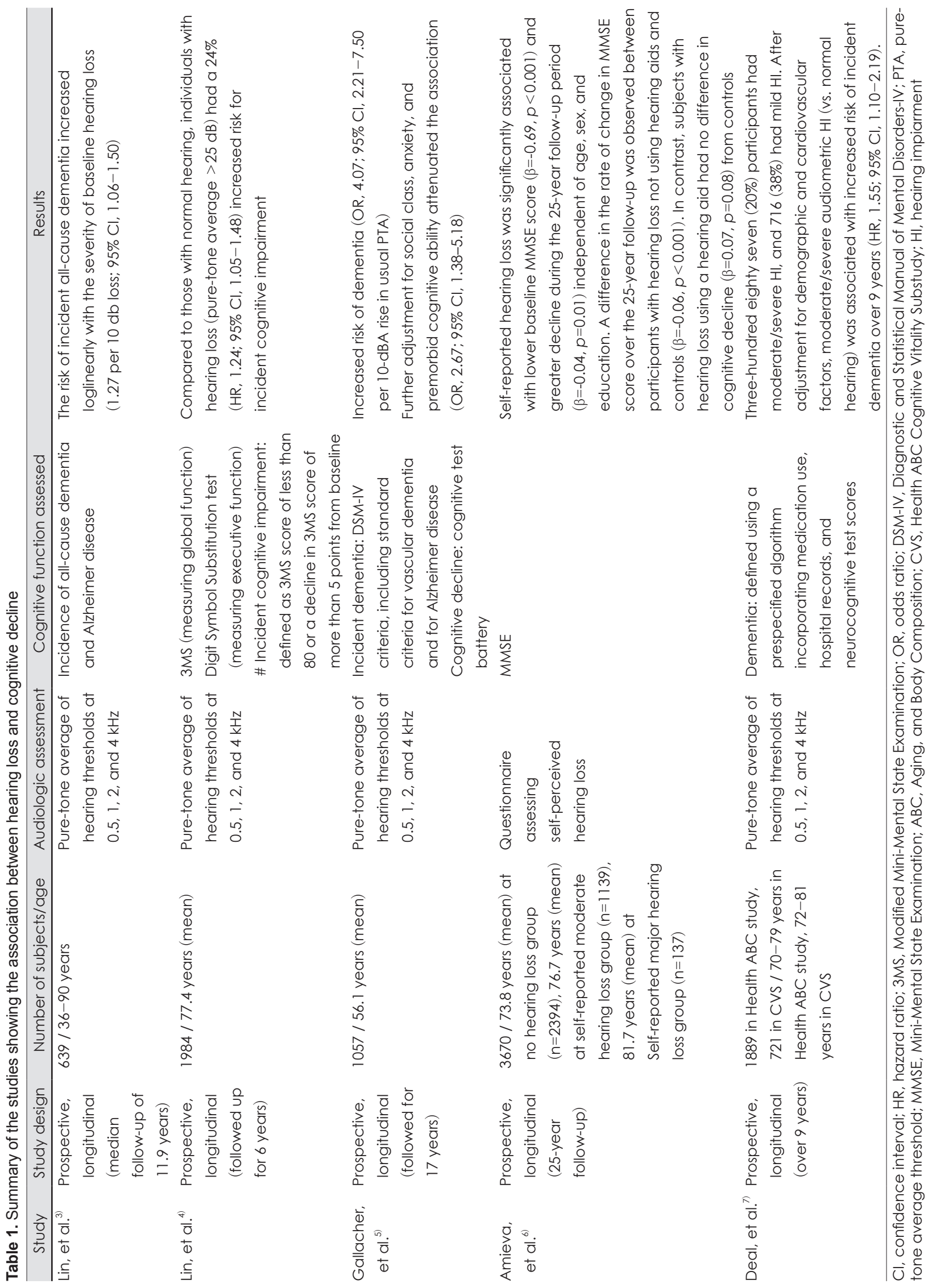


적인 영향을 미칠 수 있음을 시사할 수 있다. 본 연구에서는 노인 환자에서 청각장애와 인지기능 저하의 연관성 및 인공 와우 수술 후 인지기능 향상에 대한 결과를 최근 논문 리뷰 를 통해 정리하고, 인공와우 수술과 같은 청각적 중재가 인지 기능에 있어 어떤 영향을 미칠지에 대해 알아보고자 한다.

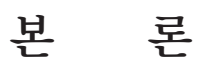

\section{노인에서 난청과 인지기능 저하의 연관성}

최근에 체계적 리뷰 및 메타 분석에 대한 많은 연구들은 노인에서 난청과 인지기능 저하 및 치매 위험의 증가 등에 관 한 연관성을 보여주고 있다..$^{14-16)} 20264$ 명을 대상으로 한 36개 의 연구들을 메타 분석한 연구에서, 노화성 난청과 인지기능 저하(odds ratio [OR], 1.22; 95\% confidence interval [CI], 1.09-1.36)와 치매(OR, 1.28; 95\% CI, 1.02-1.59)와의 유효한 연관성을 확인하였다. ${ }^{14}$

Lin 등간)은 노인에서 난청의 심각도가 가속화된 인지기능 저하와 독립적으로 연관됨을 보여주었다. 결과적으로, 인지기 능 평가에서 난청의 정도가 심할수록 더 나쁜 인지기능과 유 의미한 상관관계를 가짐을 확인할 수 있었다. 또한, $25 \mathrm{~dB} \mathrm{HL}$ 이상의 난청이 있는 경우 청력역치가 $10 \mathrm{~dB}$ 씩 증가함에 따라 치매 발생 위험이 $20 \%$ 증가한다고 보고하였다. ${ }^{3)}$ 6년간의 추 적 관찰 동안, 난청을 가진 노인은 정상 청력을 가진 노인에 비해, $30 \%-40 \%$ 의 낮은 인지기능을 보였고, 인지장애 위험 이 $24 \%$ 증가했다. ${ }^{4}$

따라서, 난청은 인지기능 저하 및 치매 발생과 독립적인 연 관성을 갖는다고 할 수 있다. 최근의 연구들에서 청력이 정상 인 성인에 비해, 경도, 중등도, 심도 난청이 있는 성인에서 치 매 발생 위험이 각각 2 배, 3 배, 5 배 이상 증가함을 보고하고 있다.,17) 또한, 최근의 전향적 코호트 연구들에서는 난청이 치 매 발생에 있어 독립적인 위험요인임을 보여주고 있다.,18-20) 난청이 치매 발생의 위험요인임을 설명하기 위해, 개체군 귀 소분획(population attributable fraction)이라는 개념을 사 용할 수 있는데, 이는 주어진 기간 동안 난청과 같은 위험요 인이 제거되었을 때, 치매 발생이 감소하는 비율을 나타낸 다. ${ }^{11)}$ 치매 발생에서 난청의 귀소분획은 $23.0 \%$ 로, 이는 우울 (10.1\%), 사회적 고립(5.9\%), 흡연(13.9\%), 고혈압(5.1\%), 당뇨 (3.2\%) 등의 다른 위험요인들보다 가장 높은 수치이다. ${ }^{11)}$ 난 청과 인지기능 저하 및 치매 발생 사이에 인과관계가 정립된 다면, 보청기나 인공와우와 같은 청각재활을 통한 청력의 향 상이 감각저하와 노화와 관련된 인지기능 저하를 완화시킬 수 있을 것이다. ${ }^{21}$

노화성 난청과 인지기능 저하의 관련성을 설명 가능한 기
전이 아직 명확하게 밝혀지지 않았지만, 노화성 난청이 치매 에 기여할 수 있음을 설명하는 잠재적인 원인 가설들이 있다 (Fig. 1). 크게 2가지 가설이 있는데, causal mechanism과 common mechanism이다. 그 중 causal mechanism을 설명 하는 2 가지 가설이 있다.

첫째, 이 둘의 관계가 인과관계(causal mechanism)라는 가설로, cognitive load hypothesis와 cascade hypothesis 등이 있다. Cognitive load hypothesis란, 난청으로 인하여 청각 인지 과정을 위해 더 많은 인지 자원을 필요로 하고, 다 른 인지 과정에 사용되는 자원을 청취노력 쪽으로 전환하게 되어, 결국 인지적 예비율(cognitive reserve) 감소를 유발한 다는 가설이다. ${ }^{22-25)}$ 즉, 청각 지각 처리에 쏟는 과도한 인지 부하(cognitive load)가 뇌의 구조적 변화와 다른 인지 과정 의 손상과 관련된 신경의 퇴행을 유발하며, 인지기능의 저하 를 일으키게 된다. ${ }^{26)}$ Cascade hypothesis에서는, 노화성 난 청이 뇌 구조에 변화를 일으키고 치매 위험을 증가시킨다는 것이다. 난청을 가진 노인들의 MRI에서 일차 청각 피질의 부 피 감소를 보였고, ${ }^{27,28)}$ 이런 뇌부피의 감소는 잠재적으로 치 매 위험 증가를 유발할 수 있는 인지 과정에 영향을 미칠 수 있다는 것이다. Cascade hypothesis를 설명하는 또 다른 가 설은 사회적 고립이다. 노화성 난청 환자에서의 의사소통의 실패는 사회적 통합을 심각하게 제한하며, 이런 사회화의 감 소는 사회적 고립, 고독감과 우울증을 일으키게 된다. ${ }^{29-34)}$ 우 울증과 사회적 고립은 청각장애와 인지장애 사이를 매개하 는 역할을 하며 청각장애와 관련된 이러한 문제는 직간접적 으로 인지장애를 유발하게 된다.

둘째, common mechanism 가설은 노화성 난청 그 자체 가 치매를 일으키는 것이 아니라, 치매와 노화성 난청에 기여 하는 공통 기전이 있다는 것이다. 즉, 노화성 난청과 인지기능 저하가 원인 관계가 아니라 공통의 원인에 의해 발생하고 서 로 독립적으로 발생하며, ${ }^{26)}$ 뇌의 노화과정에서 공통적인 신경 퇴화 과정의 결과라고 할 수 있다는 것이다. ${ }^{22)}$ 이외에도 노화

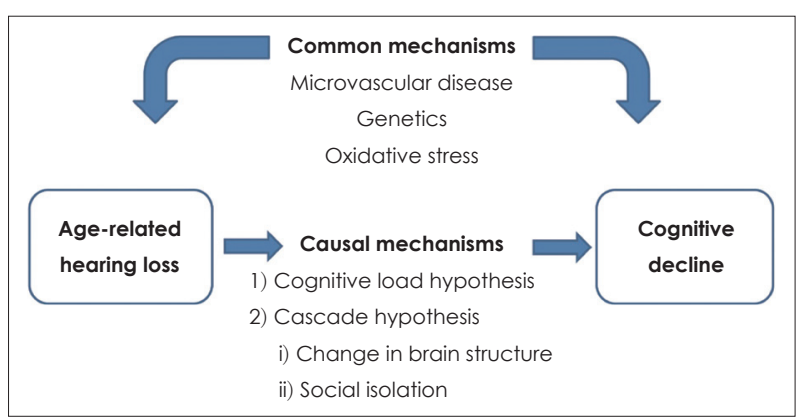

Fig. 1. Conceptual model of the association of age-related hearing loss with cognitive decline. Adapted from Chung. Korean J Otorhinolaryngol-Head Neck Surg 2020;63(4):145-53.9) 
성 난청과 인지기능 저하 사이의 연관성을 설명하기 위해 최 근 노쇠(frailty)와 관련된 가설도 제기되고 있지만 ${ }^{35,36)}$ 이 둘 간의 정확한 인과관계의 확립을 위해 많은 후속 연구들이 필 요할 것으로 생각된다.

\section{노인 환자에서 인공와우 수술 후 결과}

인공와우 수술이 고심도 난청의 표준적인 치료법으로 인정 되면서, 수술 건수가 증가하고 수술 적응증의 범위도 확대되 고 있다. ${ }^{37)}$ 또한 인공와우 이식술 이후 획기적으로 개선된 청 력재활의 결과에 대한 보고가 많았으나, 이는 주로 소아나 성 인 환자에 국한되었다. 그러나, 최근 노령 인구의 증가에 따라, 노인 환자에서의 인공와우 수술이 증가함에 따라 이에 대한 연구 결과가 많이 보고되고 있다. 노인 환자에서 인공와우 이 식술 시행 후 젊은 나이의 대조군과 비교하여 술후 언어수행 력에 차이가 없음이 보고되었고, ${ }^{38,39)}$ 삶의 질적인 측면에서도 노인 환자에서 와우이식술 후 향상된 결과가 보고되었다. ${ }^{40}$ 노인 환자에서 인공와우 수술 후 언어수행력 결과를 보고한 많은 연구들이 있다. Vermeire 등 이은 인공와우 이식술 이후 2 년간 89 명의 언어습득 후 난청을 가진 성인 환자들을 분석 하였고, 이식 시의 연령은 평균 58세(17-83세)였으며, 난청의 기간이나 보청기 사용 유무에 대한 언급은 없었다. 이 중 25 명은 70세 이상의 환자들이었고, 70세 이하 환자군과의 비교 에서 언어수행력에 유의미한 차이가 없었다. Budenz 등 ${ }^{41)}$ 은 언어습득 후 난청을 가진 성인 환자들에서 70세 이상의 환 자 60명과 18-69세 사이의 환자 48명의 언어수행력을 2년간 경과 관찰 하였다. 노인 환자군에서 이식 시 평균연령은 $76 \pm$ 4.0세(70-86세)였고, 젊은 환자군에서 평균연령은 47.9 \pm 10.8

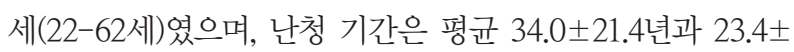
17.9 년으로 두 군 간의 유의한 차이를 보였다 $(p=0.01)$. 인공 와우 이식술 후 언어수행력에서 노인 환자군에서 유의미한 향 상을 보였다. 두 군 모두 첫 3개월에 언어분별력(speech discrimination)의 빠른 향상을 보였고, 언어수행력에서도 비슷 한 성장 속도를 보였다. 비록 노인 환자군의 언어수행력이 평 균적으로 젊은 환자군에 비해 낮았지만, 이는 연령의 차이에 의한 것이 아니라 두 군 간의 난청 기간의 차이에 의한 것으 로 생각된다. Lenarz 등 ${ }^{42}$ 은 1005명의 언어습득기 후 난청 환자 중에서 70세 이상의 환자 130명(Group 4)과 18-69세 사이의 환자 875 명을 2 년간 비교 분석하였고, 젊은 환자들은 나이에 따라, Group 1 (18-39세, n=220), Group 2 (40-59세, $\mathrm{n}=420$ ), Group 3 (60-69세, $\mathrm{n}=235$ )로 분류하였다. 노인 환자 군은 인공와우 이식술 이후 젊은 환자군과 유사한 학습곡선 (learning curve)을 보였고, 조용한 환경에서 언어 평가에서도 젊은 환자군과 비슷한 수행력을 보였다. 언어 수행력은 6 개월
째 안정적인 수준에 도달하였으며, 2 년간 수행력의 감소는 관찰되지 않았다. 특히 이 연구에서는 연령 이외에 인공와우 이식술 결과에 영향을 미칠 수 있는 잠재적인 교란 요소로 생 각되는 난청 기간, 수술 전 청력 수준, 임플란트 시스템의 유 형 등을 같이 평가하였고, 노인 환자군과 젊은 환자군 사이에 이 세 가지 요인에 대해 유의미한 차이가 없었다. 즉 언어습득 기 후 난청을 가진 노인 환자에서 인공와우 이식술 이후 음성 인식(speech perception)은 환자의 연령과 상관없이 크게 향 상되었고, ${ }^{43)}$ 이것은 이식 시 연령만을 술후 청력 결과의 예측 인자로 고려할 것이 아니라, 난청 기간과 같은 보다 명확한 예 측인자가 고려되어야 함을 의미한다. 또한, 최근의 연구들에 서도 언어습득기 후 난청을 가진 노인 환자에서 인공와우 수 술 후 청각학적 결과는 이식 연령과 유의미한 상관관계가 없 음을 보고하고 있다. ${ }^{44-46)}$ 따라서, 인공와우 수술은 고심도의 난청을 가진 고령의 환자에게 청각학적 수행력, 건강 상태, 사 회적 상호작용에 있어 현저한 개선의 결과를 줄 수 있는 안전 하고 효과적인 치료법임을 시사한다. ${ }^{43}$

\section{노인 환자에서 인공와우 수술이 인지기능에 미치는 영향}

치매를 치료하는 데 있어 효과적인 치료가 아직 없기 때문 에, 인지 기능 저하에 대한 수정 가능한 위험 요소를 관리하 는 것이 개인과 사회에 지대한 영향을 미칠 수 있을 것이다. 따라서 난청이 인지기능 저하의 일차적인 개선 가능한 위험 요소가 되기 때문에, 보청기나 인공와우 같은 청각적 중재가 인지기능 저하 및 치매와 관련된 결과를 상당히 개선시킬 것 이라 예상된다. 이는 인공와우 수술이 인지기능 향상에 미치 는 영향에 대해 살펴본 몇몇 연구에서 확인할 수 있다.

프랑스에서 10 개의 3 차 의료기관에서 수행한 전향적 연구 에서 65-85세의 환자 94명에서 인공와우 수술 전, 수술 후 6 개월, 12 개월 후 인지기능을 평가하였다. ${ }^{47)}$ 수술 전 낮은 인 지기능 점수를 받은 환자들의 $80 \%$ 이상에서 인공와우 수술 후 12 개월째 인지기능의 향상을 보였고, 인공와우를 통한 청 각적 재활이 노인들에게 손상된 인지기능의 개선과 관련이 있다는 결론을 내었다. 노인 환자에서 인공와우 수술 후 인 지기능의 결과를 보여주는 체계적 리뷰에 관한 연구에서는, 166 명의 환자가 포함된 선택된 6 개의 연구 중 5 개에서 인공 와우 수술 후 인지기능의 향상을 보고하였고, ${ }^{47-51)}$ 오직 한 개 의 연구에서만 수술 이후 인지 수행력에 유의한 변화가 보이 지 않았다고 보고하였다. ${ }^{52)}$ Table 2에서 노인 환자에서 인공 와우 이식술이 인지기능에 미치는 영향에 대한 6 개의 연구 들을 정리하였다.

Ohta 등 ${ }^{53)}$ 은 21명의 65세 이상 환자에서 인공와우 이식술 수술 전, 수술 후 1년, 2년까지 Mini-Mental State Exami- 


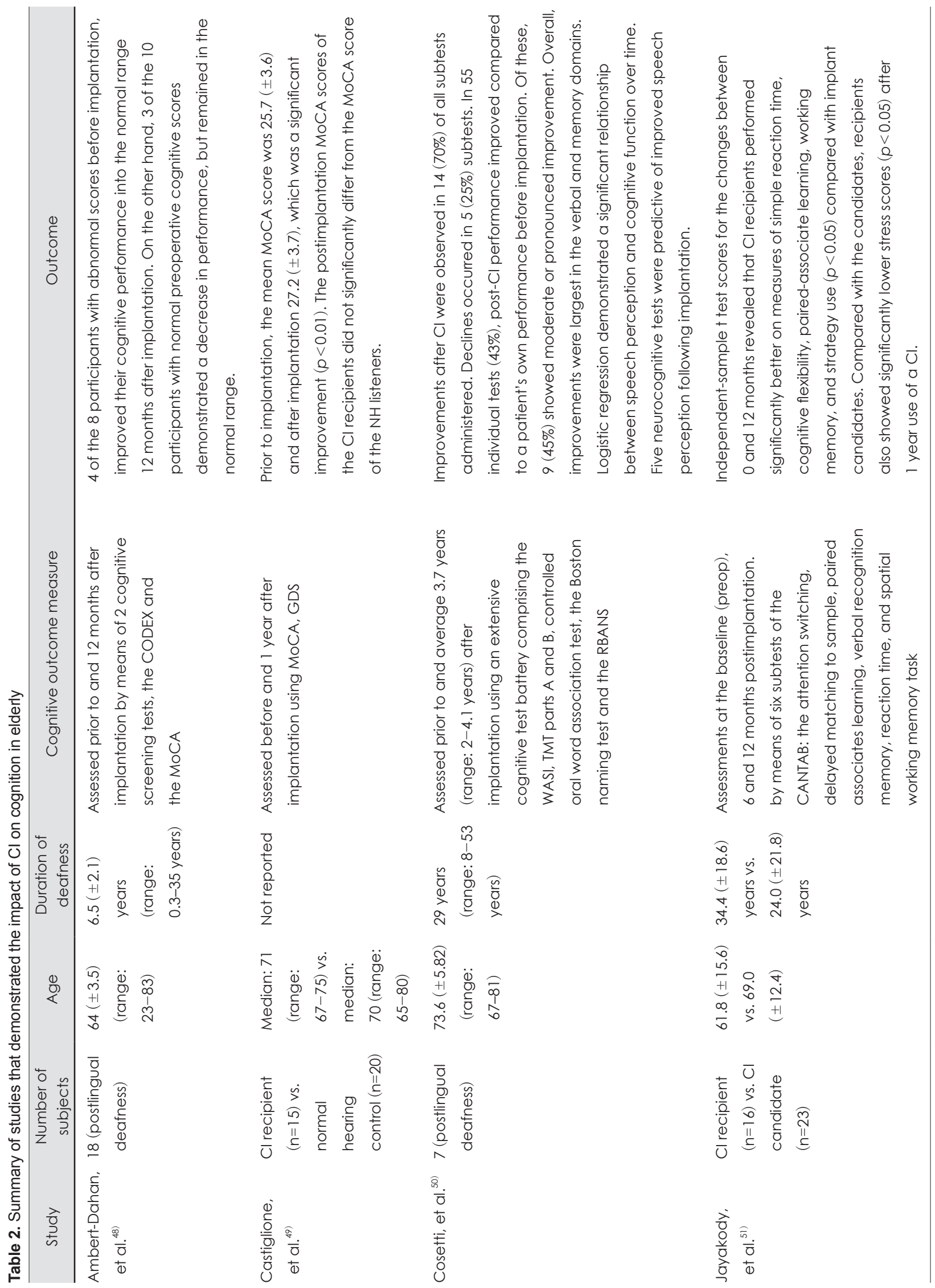




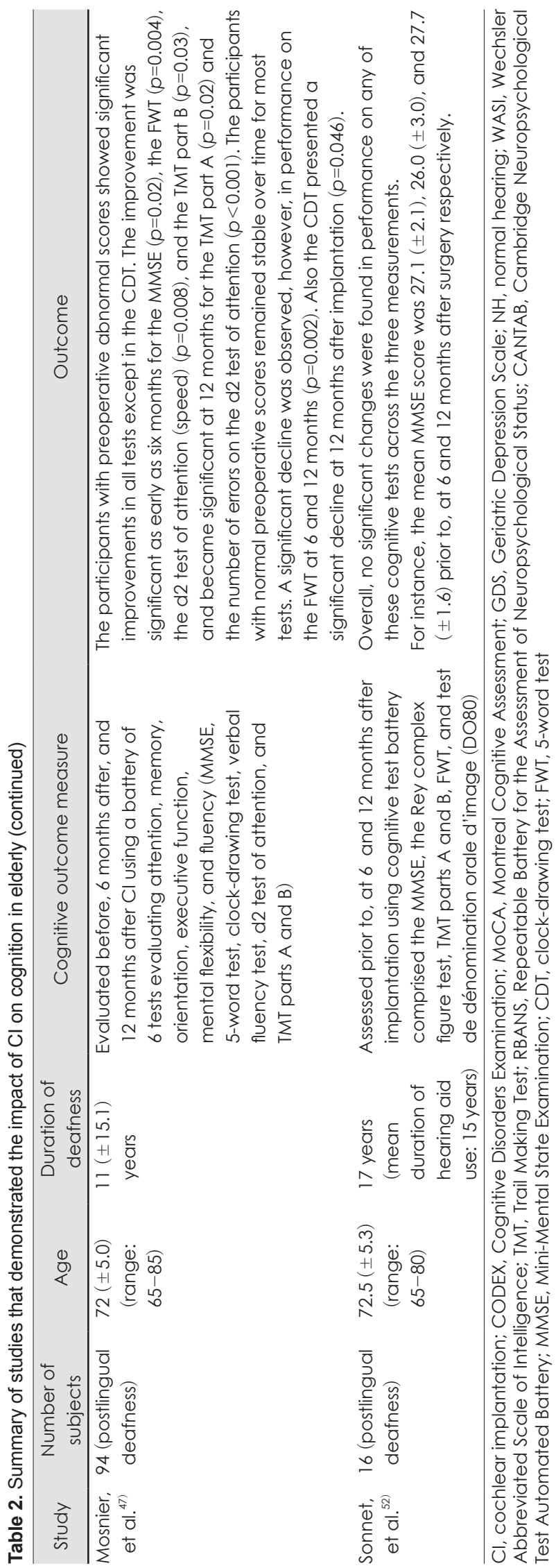

nation (MMSE)으로 인지기능을 평가하였을 때, 음성 생성 (speech production)은 인공와우 이식술 이후 인지기능 향상 을 위해 중요하며, 인지기능의 향상은 인공와우 이식술 이후 1 년째 최고점에 이르게 됨을 보고하였다. 비록 노인 환자에서 고심도의 난청이 인지기능 저하를 악화시키지만, 인공와우 이식술은 MMSE 점수가 최고점인 1년 후(즉, 인공와우 이식 술 이후 2년째) 감소하더라도 인지 기능에 긍정적인 영향을 미 친다고 보고하였다. ${ }^{53)}$ 또한, 청각에 기반하여 다른 사람들과 대화하는 것은 인지기능을 향상시키기 위해 매우 중요하며, 단순히 청각 수준과 음성 인식(speech recognition)이 향상되 는 것만으로는 부족함을 시사하였다. 따라서, 고령의 인공와 우 이식술 환자에서 청각보상을 기반으로 한 대화능력 향상 을 목표로 한 재활이 치매 예방의 핵심 전략이 될 것이다. ${ }^{53)}$

65세 이상의 고령 인공와우 이식술 환자 70 명에 대한 연구 에서, 경도인지장애(mild cognitive impairment) 확률은 $45 \%$ 로, ${ }^{44)}$ 같은 나이의 일반인이 $3 \%-19 \%$ 인 것에 비해 높았고, ${ }^{54}$ 인공와우 이식술 후 청각재활이 의사소통, 삶의 질, 인지기능 향상에 긍정적 효과를 보여 치매로의 이행이 줄어듦을 보여 주었다. 이는 난청에 의한 경도인지장애는 인지기능에 있어 청각재활에 의해 긍적적 효과를 갖는 아형(subtype)일 것이 라는 가정을 할 수 있다. ${ }^{44)}$ 따라서, 특히 경도인지장애를 가지 는 고심도의 난청 환자에서 지체 없이 인공와우 수술을 제안 하는 중요성을 강조하고 있다.4) 따라서, 심도의 난청을 가진 노인 환자에서 경도인지장애와 같은 cognitive syndrome을 특정 지을 수 있는 바이오마커나 신경학적 영상검사(neuroimaging) 같은 추가적 검사가 필요할 것이고 특히, 경도인지 장애와 같은 인지기능 저하가 있는 환자의 경우 인공와우 이 식술을 통해 인지기능 저하를 역전시켜 치매로의 이환을 예 방할 수 있을 것이다. ${ }^{44)}$

위와 같은 많은 연구들에서 인공와우 이식술 이후 인지기 능이 향상됨에 대한 명백한 결과를 얻었다. 그러나 여전히 남 는 의문은 인공와우 이식술 이후의 인지적 개선이 청각과 관 련된 인지적 저하를 완전히 역전시킬 수 있을 만큼 충분히 큰 지 여부에 대한 핵심 의문으로 남아 있다. 이런 의문은 인공 와우 이식술 이후 난청 환자들을 연령이 매치된 정상 청력의 대조군과의 비교를 통해 해결할 수 있다. ${ }^{55)}$ 또한, 인지기능 검 사 중 일부 항목들은 지시문이나 수행과정이 청각적 표현으 로 되어있거나, 검사 수행과정에서 구어를 반복하는 등 청각 에 의존해야 하는 언어 과제이기 때문에, 난청으로 인해 검사 수행이 어려워 난청인에서 인지기능이 저평가되는 경우들이 있다. 이렇게 청각적 표현에 의존하는 인지기능 검사에서 인 공와우 이식술 이후 관찰된 변화는 단순히 인지의 향상에 의 한다기 보다는 청력개선의 결과일 수 있다. ${ }^{55)}$ 청력개선에 의 
한 인지기능 향상 효과를 배제하기 위해서는 청력에 의존하 지 않는 인지기능 검사나, 기존 검사의 변형이 필요할 것이다. 2021년 Huber 등 ${ }^{55)}$ 은 나이, 성별, 교육 정도를 매칭한 정상 청력군과의 비교를 통해, 인공와우 이식술 전과 수술 후 12 개 월째 인지기능 수행을 평가하였다. 이 연구에서, 정상 청력군 과 비교하여 확연한 차이를 보이는 일부의 특정 인지 기술만 이 인공와우 이식술 후 보상될 수 있었다. 정상 청력군과 동 등한 결과는 계획(planning), 조정(coordination), 주의력 조 절(attentional control)을 필요로 하는 인지 과업이었다. 지연 회상(delayed recall), 언어성 기억회상(verbal retrieval), 억제 (inhibition), 인지적 유연성(cognitive flexibility)을 강조하는 인지적 과업의 수행은 인공와우 이식술 환자에서 더 열등하 였다. ${ }^{55)}$ 또한, 인지 기능의 향상은 수술 후 12 개월이 아닌 3 개 월째 음성 인식(speech recognition) 결과와 관련이 있었다. ${ }^{55)}$

\section{결 론}

노인에서 난청과 인지기능 저하는 높은 관련성을 가진다. 또한, 노화성 난청은 인지기능 저하 및 치매의 중요한 위험요 인으로 작용하기 때문에, 보청기나 인공와우 등을 통한 청각 적 재활이 치매를 예방할 수 있는 대안이 될 수 있다. 특히 고 심도 이상의 난청을 가진 노인 환자에서 인공와우 수술은 청 각적 수행력을 높일 수 있는 효과적인 청각재활 방법이다. 노 인환자에서 인공와우 수술 후 청각재활이 인지기능 향상에 긍정적 효과를 보여 치매로의 이행이 줄어들 것으로 생각된 다. 특히, 심고도의 난청을 가진 노인 환자에서 바이오마커나 신경학적 영상검사 등을 통한 경도의 인지기능 장애와 같은 인지기능 저하를 조기에 발견하여, 인공와우 같은 좀 더 적 극적인 수술적 치료를 통해 인지기능 저하를 역전시켜 치매 로의 이행을 감소시킬 수 있을 것이다. 앞으로 좀 더 청각적 영향력을 배제한 인지기능 검사와 오랜 경과 관찰 기간을 가 지는 잘 디자인된 연구를 통해 인공와우 수술이 인지기능에 미치는 영향을 좀 더 체계적으로 분석할 수 있을 것이다.

\section{Acknowledgments}

This work was supported by the National Research Foundation of Korea (NRF) grant funded by the Korea government (MSIT) (No. NRF-2020R1A2C2102660).

\section{ORCID}

Juyong Chung

https://orcid.org/0000-0001-5099-5243

\section{REFERENCES}

1) Cruickshanks KJ, Wiley TL, Tweed TS, Klein BE, Klein R, MaresPerlman JA, et al. Prevalence of hearing loss in older adults in Beaver Dam, Wisconsin. The epidemiology of hearing loss study.
Am J Epidemiol 1998;148(9):879-86.

2) Korea Centers for Disease Control and Prevention. The Eighth Korea National Health and Nutrition Examination Survey (KNHANES VIII). 2021 Dec [cited 2021 Dec 1]. https://knhanes. kdca.go.kr/knhanes/sub04/sub04_04_03.do.

3) Lin FR, Metter EJ, O'Brien RJ, Resnick SM, Zonderman AB, Ferrucci L. Hearing loss and incident dementia. Arch Neurol 2011; 68(2):214-20.

4) Lin FR, Yaffe K, Xia J, Xue QL, Harris TB, Purchase-Helzner E, et al. Hearing loss and cognitive decline in older adults. JAMA Intern Med 2013;173(4):293-9.

5) Gallacher J, Ilubaera V, Ben-Shlomo Y, Bayer A, Fish M, Babisch W, et al. Auditory threshold, phonologic demand, and incident dementia. Neurology 2012;79(15):1583-90.

6) Amieva H, Ouvrard C, Giulioli C, Meillon C, Rullier L, Dartigues JF. Self-reported hearing loss, hearing aids, and cognitive decline in elderly adults: A 25-year study. J Am Geriatr Soc 2015;63(10): 2099-104.

7) Deal JA, Betz J, Yaffe K, Harris T, Purchase-Helzner E, Satterfield $\mathrm{S}$, et al. Hearing impairment and incident dementia and cognitive decline in older adults: The health ABC study. J Gerontol A Biol Sci Med Sci 2017;72(5):703-9.

8) Davis A, McMahon CM, Pichora-Fuller KM, Russ S, Lin F, Olusanya BO, et al. Aging and hearing health: The life-course approach. Gerontologist 2016;56(Suppl 2):S256-67.

9) Chung J. Association of age-related hearing loss with cognitive decline. Korean J Otorhinolaryngol-Head Neck Surg 2020;63(4): 145-53.

10) Livingston G, Huntley J, Sommerlad A, Ames D, Ballard C, Banerjee S, et al. Dementia prevention, intervention, and care: 2020 report of the Lancet Commission. Lancet 2020;396(10248):413-46.

11) Livingston G, Sommerlad A, Orgeta V, Costafreda SG, Huntley J, Ames D, et al. Dementia prevention, intervention, and care. Lancet 2017;390(10113):2673-734.

12) van Hooren SA, Anteunis LJ, Valentijn SA, Bosma H, Ponds RW, Jolles J, et al. Does cognitive function in older adults with hearing impairment improve by hearing aid use? Int J Audiol 2005;44(5): 265-71.

13) Valentijn SA, van Boxtel MP, van Hooren SA, Bosma H, Beckers $\mathrm{HJ}$, Ponds RW, et al. Change in sensory functioning predicts change in cognitive functioning: Results from a 6-year follow-up in the maastricht aging study. J Am Geriatr Soc 2005;53(3):374-80.

14) Loughrey DG, Kelly ME, Kelley GA, Brennan S, Lawlor BA. Association of age-related hearing loss with cognitive function, cognitive impairment, and dementia: A systematic review and meta-analysis. JAMA Otolaryngol Head Neck Surg 2018;144(2): $115-26$.

15) Wei J, Hu Y, Zhang L, Hao Q, Yang R, Lu H, et al. Hearing impairment, mild cognitive impairment, and dementia: A metaanalysis of cohort studies. Dement Geriatr Cogn Dis Extra 2017; 7(3):440-52.

16) Ford AH, Hankey GJ, Yeap BB, Golledge J, Flicker L, Almeida OP. Hearing loss and the risk of dementia in later life. Maturitas 2018:112:1-11.

17) Foster SM, Davis HP, Kisley MA. Brain responses to emotional images related to cognitive ability in older adults. Psychol Aging 2013;28(1):179-90.

18) Gurgel RK, Ward PD, Schwartz S, Norton MC, Foster NL, Tschanz JT. Relationship of hearing loss and dementia: A prospective, population-based study. Otol Neurotol 2014;35(5):775-81.

19) Quaranta N, Coppola F, Casulli M, Barulli O, Lanza F, Tortelli R, et al. The prevalence of peripheral and central hearing impairment and its relation to cognition in older adults. Audiol Neurootol 2014; 19(suppl 1):10-4. 
20) Golub JS, Luchsinger JA, Manly JJ, Stern Y, Mayeux R, Schupf N. Observed hearing loss and incident dementia in a multiethnic cohort. J Am Geriatr Soc 2017;65(8):1691-7.

21) Miller G, Miller C, Marrone N, Howe C, Fain M, Jacob A. The impact of cochlear implantation on cognition in older adults: $\mathrm{A}$ systematic review of clinical evidence. BMC Geriatr 2015;15:16.

22) Wayne RV, Johnsrude IS. A review of causal mechanisms underlying the link between age-related hearing loss and cognitive decline. Ageing Res Rev 2015;23(Pt B):154-66.

23) Tun PA, McCoy S, Wingfield A. Aging, hearing acuity, and the attentional costs of effortful listening. Psychol Aging 2009;24(3): 761-6.

24) Martini A, Castiglione A, Bovo R, Vallesi A, Gabelli C. Aging, cognitive load, dementia and hearing loss. Audiol Neurootol 2014; 19(suppl 1):2-5.

25) Chern A, Golub JS. Age-related hearing loss and dementia. Alzheimer Dis Assoc Disord 2019;33(3):285-90.

26) Uchida Y, Sugiura S, Nishita Y, Saji N, Sone M, Ueda H. Age-related hearing loss and cognitive decline - The potential mechanisms linking the two. Auris Nasus Larynx 2019;46(1):1-9.

27) Peelle JE, Troiani V, Grossman M, Wingfield A. Hearing loss in older adults affects neural systems supporting speech comprehension. J Neurosci 2011;31(35):12638-43.

28) Eckert MA, Cute SL, Vaden KI Jr, Kuchinsky SE, Dubno JR. Auditory cortex signs of age-related hearing loss. J Assoc Res Otolaryngol 2012;13(5):703-13.

29) Mick P, Kawachi I, Lin FR. The association between hearing loss and social isolation in older adults. Otolaryngol Head Neck Surg 2014;150(3):378-84.

30) Dawes P, Emsley R, Cruickshanks KJ, Moore DR, Fortnum H, Edmondson-Jones $\mathrm{M}$, et al. Hearing loss and cognition: The role of hearing AIDS, social isolation and depression. PLoS One 2015; 10(3): 0119616

31) Sugawara N, Sasaki A, Yasui-Furukori N, Kakehata S, Umeda T, Namba A, et al. Hearing impairment and cognitive function among a community-dwelling population in Japan. Ann Gen Psychiatry 2011;10(1):27.

32) Amieva H, Ouvrard C, Meillon C, Rullier L, Dartigues JF. Death, depression, disability, and dementia associated with self-reported hearing problems: A 25-year study. J Gerontol A Biol Sci Med Sci 2018;73(10):1383-9.

33) Rutherford BR, Brewster K, Golub JS, Kim AH, Roose SP. Sensation and psychiatry: Linking age-related hearing loss to latelife depression and cognitive decline. Am J Psychiatry 2018;175(3): 215-24.

34) Kiely KM, Anstey KJ, Luszcz MA. Dual sensory loss and depressive symptoms: The importance of hearing, daily functioning, and activity engagement. Front Hum Neurosci 2013;7:837.

35) Panza F, Lozupone M, Sardone R, Battista P, Piccininni M, Dibello $\mathrm{V}$, et al. Sensorial frailty: Age-related hearing loss and the risk of cognitive impairment and dementia in later life. Ther Adv Chronic Dis 2018;10:2040622318811000.

36) Jayakody DMP, Friedland PL, Martins RN, Sohrabi HR. Impact of aging on the auditory system and related cognitive functions: A narrative review. Front Neurosci 2018;12:125.

37) Haensel J, Ilgner J, Chen YS, Thuermer C, Westhofen M. Speech perception in elderly patients following cochlear implantation. Acta Otolaryngol 2005;125(12):1272-6.

38) Kelsall DC, Shallop JK, Burnelli T. Cochlear implantation in the elderly. Am J Otol 1995;16(5):609-15.
39) Chatelin V, Kim EJ, Driscoll C, Larky J, Polite C, Price L, et al. Cochlear implant outcomes in the elderly. Otol Neurotol 2004;25(3): 298-301.

40) Vermeire K, Brokx JP, Wuyts FL, Cochet E, Hofkens A, Van de Heyning PH. Quality-of-life benefit from cochlear implantation in the elderly. Otol Neurotol 2005;26(2):188-95.

41) Budenz CL, Cosetti MK, Coelho DH, Birenbaum B, Babb J, Waltzman SB, et al. The effects of cochlear implantation on speech perception in older adults. J Am Geriatr Soc 2011;59(3):446-53.

42) Lenarz M, Sönmez H, Joseph G, Büchner A, Lenarz T. Cochlear implant performance in geriatric patients. Laryngoscope 2013; 122(6):1361-5.

43) Amin N, Wong G, Nunn T, Jiang D, Pai I. The outcomes of cochlear implantation in elderly patients: A single United Kingdom center experience. Ear Nose Throat J 2021;100(5_suppl):842S-7S.

44) Mosnier I, Vanier A, Bonnard D, Lina-Granade G, Truy E, Bordure $\mathrm{P}$, et al. Long-term cognitive prognosis of profoundly deaf older adults after hearing rehabilitation using cochlear implants. J Am Geriatr Soc 2018;66(8):1553-61.

45) Wong DJ, Moran M, O’Leary SJ. Outcomes after cochlear implantation in the very elderly. Otol Neurotol 2016;37(1):46-51.

46) Garcia-Iza L, Martinez Z, Ugarte A, Fernandez M, Altuna X. Cochlear implantation in the elderly: Outcomes, long-term evolution, and predictive factors. Eur Arch Otorhinolaryngol 2018;275(4):91322.

47) Mosnier I, Bebear JP, Marx M, Fraysse B, Truy E, Lina-Granade G, et al. Improvement of cognitive function after cochlear implantation in elderly patients. JAMA Otolaryngol Head Neck Surg 2015;141(5): 442-50.

48) Ambert-Dahan E, Routier S, Marot L, Bouccara D, Sterkers O, Ferrary E, et al. Cognitive evaluation of cochlear implanted adults using CODEX and MoCA screening tests. Otol Neurotol 2017; 38(8):e282-4.

49) Castiglione A, Benatti A, Velardita C, Favaro D, Padoan E, Severi $\mathrm{D}$, et al. Aging, cognitive decline and hearing loss: Effects of auditory rehabilitation and training with hearing aids and cochlear implants on cognitive function and depression among older adults. Audiol Neurootol 2016;21(1):21-8.

50) Cosetti MK, Pinkston JB, Flores JM, Friedmann DR, Jones CB, Roland JT Jr, et al. Neurocognitive testing and cochlear implantation: Insights into performance in older adults. Clin Interv Aging 2016; 11:603-13

51) Jayakody DMP, Friedland PL, Nel E, Martins RN, Atlas MD, Sohrabi HR. Impact of cochlear implantation on cognitive functions of older adults: Pilot test results. Otol Neurotol 2017;38(8):e289-95.

52) Sonnet MH, Montaut-Verient B, Niemier JY, Hoen M, Ribeyre L, Parietti-Winkler C. Cognitive abilities and quality of life after cochlear implantation in the elderly. Otol Neurotol 2017;38(8):e296301.

53) Ohta Y, Imai T, Maekawa Y, Morihana T, Osaki Y, Sato T, et al. The effect of cochlear implants on cognitive function in older adults: A prospective, longitudinal 2-year follow-up study. Auris Nasus Larynx. In press 2021

54) Gauthier S, Reisberg B, Zaudig M, Petersen RC, Ritchie K, Broich K, et al. Mild cognitive impairment. Lancet 2006;367(9518):126270.

55) Huber M, Roesch S, Pletzer B, Lukaschyk J, Lesinski-Schiedat A, Illg A. Can cochlear implantation in older adults reverse cognitive decline due to hearing loss? Ear Hear 2021;42(6):1560-76. 


\section{정답 및 해설}

1. 답 (2)

해설 우측 귀의 incus가 소실된 경우로, 중이의 소리 전달 기전이 파괴되어 전음성 난청 소견을 보인다. 이소골 성형술을 통해 청력개선이 될 수 있다.

참고 문헌: 대한이비인후과학회. 이비인후과학:이과. 개정2판. 파주: 군자출판사;2018. p.206-7.

2. 답 (1)

해설 상고실 진주종(attic cholesteatoma)은 이관의 기능부전으로 인한 중이 내의 음압으로 섬유조직이 적고 지지하는 힘이 적은 고막의 이완부에서 주로 발생한다. 반복되는 염증으로 고막 합입낭이 형성되고 깊어지면서, 내함낭의 주머니 안에 서 상피세포의 이동이 저하되고 탈락 상피가 빠져 나오지 못하게 되면, 게속 케라틴이 축적되면서 내함낭이 폐쇄된 공간 속으로 점차 자라 들어가 진주종을 형성하게 된다.

참고 문헌: 대한이비인후과학회. 이비인후과학:이과. 개정2판. 군자출판사;2018. p.418. 